\title{
Spatial and temporal variations
}

\author{
S. M. Limbu ${ }^{1,2^{*}}$ and M. S. Kyewalyanga ${ }^{3}$
}

\section{${ }^{*}$ Correspondence:}

mchelelimbu@yahoo.com

${ }^{1}$ Department of Aquatic

Sciences and Fisheries,

University of Dar es Salaam,

P.O. Box 35064, Dar es Salaam,

Tanzania

Full list of author information

is available at the end of the article

\begin{abstract}
Phytoplankton can indirectly indicate health status of coral reefs due to their sensitivity to changes in water quality parameters. This study explored the spatial and temporal variability in water quality and nutrients in relation to phytoplankton community composition and chlorophyll a concentration at Bawe, Mnemba, Chumbe and Pongwe coral reef sites in Unguja Island. In situ measurements of dissolved oxygen, temperature, salinity and $\mathrm{pH}$ were done every month for 1 year. Surface water samples were collected for determination of phytoplankton composition, nutrients and chlorophyll a concentration. Dissolved oxygen, temperature, salinity and pH did not differ significantly among the four sites ( $p>0.05$ ) but showed significant temporal variations among months $(p<0.05)$. Bawe had significantly higher phosphate concentration $\left(1.45 \pm 0.57 \mu \mathrm{g} \mathrm{L}^{-1}\right)$ than Chumbe $\left(0.74 \pm 0.53 \mu \mathrm{g} \mathrm{L}^{-1}\right)$, Mnemba $\left(0.42 \pm 0.30 \mu \mathrm{g} \mathrm{L}^{-1}\right)$ and Pongwe $(0.28 \pm 0.10 \mu \mathrm{g} \mathrm{L}-1 ; p<0.05)$. Similarly, Bawe had significantly higher nitrate concentration $\left(0.81 \pm 0.43 \mu \mathrm{g} \mathrm{L}^{-1}\right)$ than Mnemba $\left(0.33 \pm 0.14 \mu \mathrm{g} \mathrm{L}^{-1}\right)$ and Pongwe $(0.24 \pm 0.13 \mu \mathrm{g} \mathrm{L}-1 ;<0.05)$ but similar to Chumbe $\left(0.90 \pm 0.35 \mu \mathrm{g} \mathrm{L}^{-1}\right.$; $p>0.05)$. However, values obtained at all the studied sites were less than 3 and $14 \mathrm{mg} \mathrm{L}^{-1}$ for phosphate and nitrate, respectively, for eutrophic oceans. Phytoplankton species were dominated by Bacillariophyceae $(70.83 \%)$ and some species identified such as Ceratium sp., Dinophysis sp., Protoperidinium sp., Prorocentrum sp., Oscillatoria sp. and Dictyocha fibula are known to produce toxins that affect fish species. Bawe had significantly higher chlorophyll a concentration $\left(0.47 \pm 0.07 \mathrm{mg} \mathrm{L}^{-1}\right)$ than Mnemba $\left(0.33 \pm 0.04 \mathrm{mg} \mathrm{L}^{-1}\right)$ and Chumbe $\left(0.33 \pm 0.04 \mathrm{mg} \mathrm{L}^{-1} ; \mathrm{p}<0.05\right)$. Chlorophyll a concentration was spatially inversely related to distance from Unguja town $(p<0.05)$ while it was temporally significantly positively correlated with dissolved oxygen, nitrate and phosphate $(p<0.05)$. The study revealed that, the coral reef sites have low nutrient levels and are in good health. The existence of toxic phytoplankton species suggests careful consumption of fisheries resources at the four coral reef sites and frequent monitoring for Harmful Algal Blooms (HABs) is required. The higher nutrients and chlorophyll a concentrations at Bawe Island compared to other sites calls for mechanisms to limit the release of domestic sewage from households and hotels to safeguard the coral reefs.
\end{abstract}

Keywords: Unguja Island, Phytoplankton, Chlorophyll $a$, Water quality variables, Nutrients

\section{望 Springer}

( 2015 Limbu and Kyewalyanga. This article is distributed under the terms of the Creative Commons Attribution 4.0 International License (http://creativecommons.org/licenses/by/4.0/, which permits unrestricted use, distribution, and reproduction in any medium, provided you give appropriate credit to the original author(s) and the source, provide a link to the Creative Commons license, and indicate if changes were made. 


\section{Background}

Phytoplankton play an important role in the marine food web, biogeochemical cycles and climatic processes (Alvain et al. 2008; Nassar et al. 2014). They initiate the marine food chain, by serving as food to primary consumers such as zooplankton, which in turn transfer energy when consumed by higher trophic animals such as finfish (Saravanakumar et al. 2008). Moreover phytoplankton composition and abundance are considered as natural bio-indicators of water quality variations because of their sensitivity and rapid responses to changes in environmental conditions such as $\mathrm{pH}$, light, temperature, salinity, turbidity and nutrients (Ekwu and Sikoki 2006; Panda et al. 2012; Stanca et al. 2013). Thus, the species composition, relative abundance, spatial and temporal distribution of these aquatic biota are an expression of the environmental health or biological integrity of a particular water body.

Indirectly, phytoplankton can be used to provide indication of the status of coral reefs due to their sensitivity to changes in water quality parameters (Tchernov et al. 2004; Panda et al. 2012). Coral reefs are among the most productive and biologically diverse ecosystems on Earth providing almost a third of the world's marine fish species and around $10 \%$ of the fish consumed by humans (Moberg and Folke 1999; Stanca et al. 2013). Unfortunately, many coral reefs are in serious decline (De'ath et al. 2012), including those of Zanzibar particularly Unguja Island. The coral reefs in Unguja Island are situated near poor human settlement. They are affected by deforestation, intensive agriculture run off, urbanization, destructive fishing methods, uncontrolled tourism and pollution (McClanahan et al. 2007; Sachithanandam et al. 2013). Unguja's population is chronically poor and the Island's 1.5 million residents are heavily dependent on vulnerable marine resources which underpins economic activities accounting for $30 \%$ of GDP (Lange and Jiddawi 2009; Suckall et al. 2014). The release of inorganic nutrients into ocean from domestic sewage has been a major threat to many coral reefs in the area (Bjork et al. 1995). Tourism in the area has grown rapidly, increasing the demand for goods and services in already degraded shallow coral reefs surrounding the Zanzibar coast (Gössling 2001).

Nutrient over-enrichment is considered a major cause of degradation of coral reefs because it leads to a shift from low algal cover to high abundance of fleshy algae (Szmant 2002). Previous studies on coral reefs in the area have reported increased degradation of coral reefs due to growing loads of nutrients, sediments and pollutants discharged from land (Mohammed 2002; Moynihan et al. 2012). Nutrient increase has been shown to cause decreased light penetration, increased sedimentation of organic particles and rapid growth of opportunistic macroalgae (Bjork et al. 1995; Nzali et al. 1998) consequently leading to lower growth of coral reefs. In their study, Bjork et al. (1995) related the decline of the coralline algae they observed to the outlets of sewage water from Unguja town.

Despite the important services provided by corals and the alarming rate on their decline, little documented baseline data exists on algal communities, which are essential tools in assessing the biological integrity of the coral reefs. Fertility and healthiness of coral reefs are reflected through productivity of phytoplankton (Saravanakumar et al. 2008). However studies on phytoplankton abundance and distribution in the coral reefs of Zanzibar is lacking. The lack of historical data on phytoplankton and water quality parameters have been shown to limit attempts to resolve the true impacts on the coral reefs (Johnstone et al. 1998). Much work is still needed to unravel phytoplankton 
composition and patterns in many remote marine areas that remain largely unexplored, such as those of Unguja coral reefs.

The present study was carried out to analyze the spatial and seasonal variability in water quality variables relative to phytoplankton community structure, diversity and biomass (as chlorophyll $a$ concentration). The results of phytoplankton and nutrients were expected to indirectly provide insights on the health condition of coral reefs in Unguja Island. The study hypothesized that the four coral reef sites have different water quality parameters and phytoplankton community structure, diversity and biomass due to their different locations thus experience varying levels of exposure to the monsoon winds and water currents, as well as anthropogenic pressure.

\section{Methods}

\section{Study sites}

The study was conducted at four coral reefs sites in Unguja Island, Zanzibar. Zanzibar Island is in a tropical climate zone characterized by two rainy seasons; a long rainy season between March and May and a short rainy season from October to November (Lugomela et al. 2001). The area receives an average annual rainfall of between 1100 and $1500 \mathrm{~mm}$ (Lugomela et al. 2001). The tidal current at the area are semi-diurnal in nature. The Island is also under the influence of monsoon winds and circulation that affect the distribution of nutrients and marine organisms as well as biological processes (Richmond 2011; Peter 2013; Ezekiel 2014).

Four coral reef sites were selected and used during this study to represent sites which are affected by domestic waste disposal, protected areas and those influenced by tourist activities (Fig. 1). The two sampling sites: Bawe-Changuu Island and Chumbe are located on the west coast of Unguja Island whereas the other two sites: Pongwe and Mnemba Island are located on the east coast of Unguja Island. The west coast of Unguja Island is more protected, without prevailing winds and strong currents, while the east coast have high energy coast line with strong winds, currents and tides (Johnstone et al. 1998). All the sites are shallow with depths ranges between 0.50 and $3.00 \mathrm{~m}$ at low tide.

Bawe-Changuu Island sites are located at latitudes $6^{\circ} 08^{\prime} 43^{\prime \prime} \mathrm{S}$ and longitudes $39^{\circ} 08^{\prime} 10^{\prime \prime} \mathrm{E}$ and $6^{\circ} 07^{\prime} 28^{\prime \prime} \mathrm{S}$ and $39^{\circ} 98^{\prime} 09^{\prime \prime} \mathrm{E}, 6.33$ and $4.80 \mathrm{~km}$, respectively west of Unguja town (Bergman et al. 2000). These reefs are recipients of the town sewage, the disposals and discharge from the harbor activities (Mbije et al. 2002). They are both surrounded by coral reefs and are popular snorkel and dive sites for tourists. During analysis, the data from these two sites were pooled due to their proximity and are herein referred to as Bawe. Chumbe Island $\left(06^{\circ} 16^{\prime} 31^{\prime \prime} \mathrm{S}, 39^{\circ} 10^{\prime} 29^{\prime \prime} \mathrm{E}\right)$ is a Marine Protected Area (MPA), located $13.20 \mathrm{~km}$ southwest of Unguja town (Bergman et al. 2000). The reef is very lush and well managed with high diversity of hard corals (Mbije et al. 2002). Mnemba Island $\left(5^{\circ} 48^{\prime} 52^{\prime \prime} \mathrm{S}, 39^{\circ} 23^{\prime} 03^{\prime \prime} \mathrm{E}\right)$ is located about $53.00 \mathrm{~km}$ away from Unguja town and has been protected from extraction of resources since 1989 (Bronstein and Loya 2014). Mnemba Atoll has been reported to have the highest species diversity among the reefs in the northern part of Unguja (Masalu 2000). Pongwe $\left(06^{\circ} 01^{\prime} 52^{\prime \prime}\right.$ S; $39^{\circ} 25^{\prime} 13^{\prime \prime}$ E) located about $33.00 \mathrm{~km}$ form Unguja town is the reef-flats of Zanzibar's eastern fringing reefs, the site is under heavy utilization from tourists, fishermen and divers (Bronstein and Loya 2014), which increases nutrients levels. 


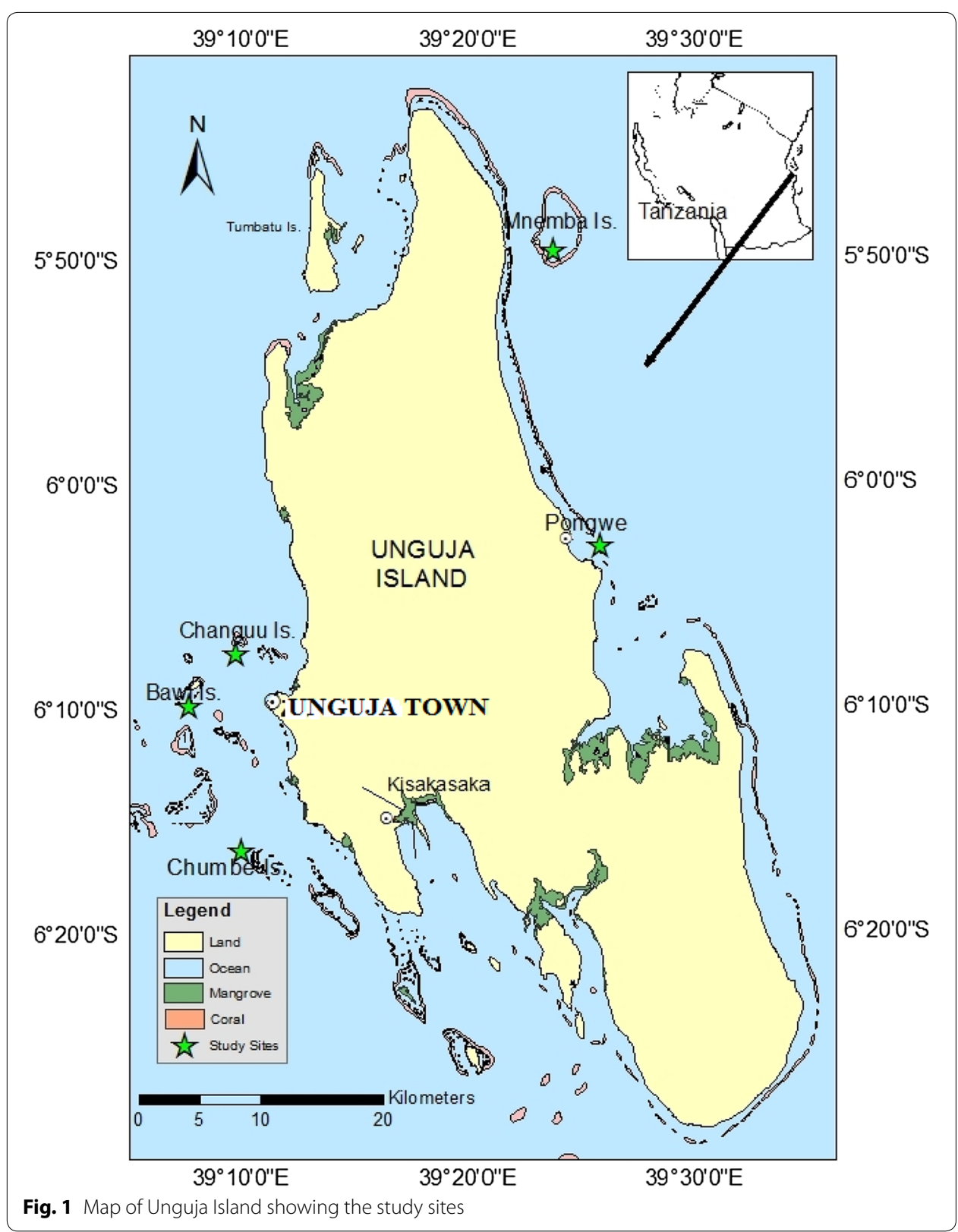

\section{Sampling procedure}

The spatial variation data for measured parameters were obtained at each site as described in the next sections. Data for temporal variation was obtained by averaging the parameter values measured from all the four sampling sites in a month to get a representative value for that particular month for further analysis.

\section{Measurement of water quality parameters}

At each site, in situ monthly sampling of dissolved oxygen, $\mathrm{pH}$ and temperature measurements were done using a Hanna hand-held pH meter (Hanna Instrument: HI 8014UK). Salinity was measured by using a refractometer (ATAGO S/MILL-Japan). For each 
parameter, three measurements were taken and their mean value calculated to represent a datum for each sampling occasion for the entire sampling period of 12 months.

\section{Determination of nutrients concentrations}

At each site, triplicate surface water samples were collected on monthly basis using a water sampler and transported to the laboratory at the Institute of Marine Sciences (IMS) of the University of Dar es Salaam for filtering using $0.25 \mu \mathrm{m}$ Whatman ${ }^{\circledR}$ GF/F filters. Analysis of phosphate and nitrate in the extracts were determined using a SHIMADZU Spectrophotometer (UV-1201-Japan) as explained in Parsons et al. (1984).

\section{Estimation of phytoplankton abundance and diversity}

Phytoplankton samples were collected by towing a plankton net ( $45 \mu$ mesh size; diameter $26 \mathrm{~cm}$ ) against the currents at subsurface level for 20-30 min. The samples were instantly preserved by fixing with 10 \% Lugol's solution and transported to IMS laboratory for phytoplankton identification. In the laboratory, identification was done using a light microscope equipped with tracing and measuring devices. Identification and classification of phytoplankton were carried out with the aid of standard monographs and publications including Round et al. (1990) and Tomas (1997). The frequency of appearance for a certain phytoplankton species or genus in a sample was used to indicate its abundance. The Shannon-Weaver diversity index (Shannon and Weaver 1949) and Shannon equitability of phytoplankton species among the four sites were estimated using species diversity and richness program developed by Henderson and Seaby (2001) using the following formulae:

1. Shannon-Weaver diversity index $\left(\mathrm{H}^{\prime}\right)=-\sum_{\mathrm{i}=1}^{\mathrm{s}} \mathrm{Pi} \ell \mathrm{n}(\mathrm{Pi})$

where the pi's are the proportion of all observations in the $i$ th species category and $\mathrm{S}$ is the total number of species.

2. Shannon equitability $\left(\mathrm{E}_{\mathrm{H}}\right)=\frac{\mathrm{H}^{\prime}}{\mathrm{H}_{\max }^{\prime}}=\frac{\mathrm{H}^{\prime}}{\ell n S}$

where $\mathrm{H}_{\max }^{\prime}=\ln \mathrm{S}$ (equitability assumes a value between 0 and 1 , where 1 indicates complete evenness).

\section{Determination of chlorophyll a concentration}

At each study site, 4-6 L of surface water samples were collected in triplicate using plastic bottles every month for determination of chlorophyll $a$ concentration for a period of 12 months. The water samples were transported to IMS for laboratory analysis. In the laboratory, water samples were filtered through $0.45 \mu \mathrm{m}$ millipore membrane filters and extracted in $90 \%$ acetone overnight at $4{ }^{\circ} \mathrm{C}$. Chlorophyll $a$ concentration was then measured using a SHIMADZU Spectrophotometer (UV-1201-Japan) according to Parsons et al. (1984).

\section{Statistical analyses}

Results are presented as mean \pm standard deviation (SD) and data were tested for normality using Shapiro-Wilk test and homogeneity of variance using Levene's test. Spatially, none of the measured parameters were normally distributed even after log 
transformation $(\mathrm{p}<0.05)$. Temporary, water temperature only was normally distributed $(\mathrm{W}=0.961, \mathrm{p}=0.226)$ and has homogeneous variance $(\mathrm{F}=1.939, \mathrm{p}=0.085)$. The other measured parameters were not normally distributed even after log transformation $(\mathrm{p}<0.05)$. Thus, temporal water temperature was analyzed using one way analysis of variance (ANOVA) followed by Tukey's post hoc test for specific differences. KruskalWallis $(\mathrm{H})$ test was utilized to determine spatial significant differences in chlorophyll $a$, dissolved oxygen, water salinity and $\mathrm{pH}$ among the four sites and temporally among the 12 sampling months. When significant differences were detected, pairwise comparisons were conducted using the Mann-Whitney $(U)$ test. Results for ANOVA and KruskalWallis tests are reported as $\mathrm{F}$ and $\mathrm{H}$ values, respectively, with subscripts in $\mathrm{F}$ results denoting degrees of freedom (df). Spearman's correlation was used to show any association among different parameters measured both spatially and temporally during the study. All statistical analyses were performed using SPSS for windows version 20 (SPSS, Inc). Results with $\mathrm{p} \leq 0.05$ were considered statistically significant for all statistical tests except Spearman's correlations which used a $\mathrm{p} \leq 0.01$.

\section{Results}

\section{Spatial variations}

Water quality parameters

Dissolved oxygen, temperature, salinity and $\mathrm{pH}$ did not differ significantly among the four sites (dissolved oxygen, $\mathrm{H}=0.602$, $\mathrm{df}=3, \mathrm{p}=0.896$; temperature, $\mathrm{H}=1.058$, $\mathrm{df}=3, \mathrm{p}=0.787$; salinity, $\mathrm{H}=0.391, \mathrm{df}=3, \mathrm{p}=0.942$ and $\mathrm{pH}, \mathrm{H}=3.030, \mathrm{df}=3$, $\mathrm{p}=0.387$; Table 1 ).

\section{Nutrients concentrations}

The values of phosphate varied between $0.28 \pm 0.10 \mu \mathrm{g} \mathrm{L}^{-1}$ and $1.45 \pm 0.57 \mu \mathrm{g} \mathrm{L}^{-1}$ recorded at Pongwe and Bawe respectively (Fig. 2). The concentration of phosphate differed significantly among the four sites $(\mathrm{H}=39.607, \mathrm{df}=3, \mathrm{p}<0.001)$. Mann-Whitney's test showed significantly higher phosphate concentration at Bawe than at Chumbe $(U=463.000, \mathrm{p}=0.037)$, Mnemba $(U=232.500, \mathrm{p}<0.001)$ and Pongwe $(U=121.500$, $\mathrm{p}<0.001)$. Similarly, the concentration of phosphate recorded at Chumbe was significantly higher than that recorded at Pongwe $(U=381.500, \mathrm{p}=0.003)$. Mnemba had significantly higher phosphate concentration than Pongwe $(U=408.500, \mathrm{p}=0.007)$. However, Mnemba had statistically similar phosphate concentration to Chumbe $(U=517.000, \mathrm{p}=0.140)$. The spatial concentration of phosphate decreased as the sampling site distance increased from Unguja town $(r=-0.415, \mathrm{p}<0.001)$.

Table 1 Water quality parameters (mean \pm SD) measured during the study period at four coral reef sampling sites

\begin{tabular}{lrrrr}
\hline Parameter & \multicolumn{1}{l}{ Pongwe } & Mnemba & \multicolumn{1}{c}{ Chumbe } & Bawe \\
\hline Temperature $\left({ }^{\circ} \mathrm{C}\right)$ & $27.72 \pm 1.20$ & $27.49 \pm 1.21$ & $27.67 \pm 1.40$ & $27.51 \pm 1.34$ \\
Salinity (ppt) & $34.92 \pm 1.46$ & $35.00 \pm 1.49$ & $34.92 \pm 2.13$ & $35.08 \pm 1.59$ \\
Dissolve oxygen $\left(\mathrm{mg} \mathrm{L}^{-1}\right)$ & $5.77 \pm 0.42$ & $5.80 \pm 0.38$ & $5.88 \pm 0.54$ & $5.78 \pm 0.39$ \\
$\mathrm{pH}$ & $7.91 \pm 0.12$ & $7.93 \pm 0.11$ & $7.93 \pm 0.12$ & $7.96 \pm 0.10$ \\
\hline
\end{tabular}




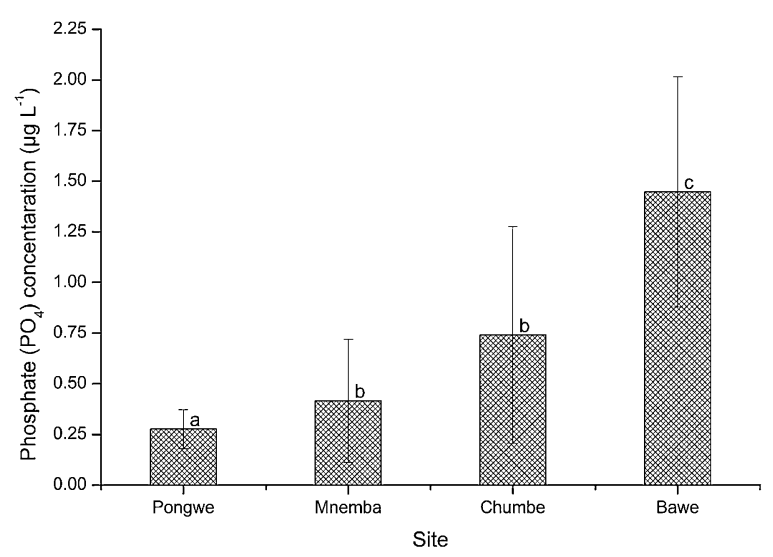

Fig. 2 The spatial variation in phosphate $\left(\mathrm{PO}_{4}\right)$ concentration at the four sites during the study period. Different letters ( $a, b$ and $c$ ) above bars indicate significant differences ( $p \leq 0.05)$

Nitrate concentration varied from a minimum value of $0.24 \pm 0.13 \mu \mathrm{g} \mathrm{L}{ }^{-1}$ recorded at Pongwe (Fig. 3). The maximum value of nitrate concentration of $0.90 \pm 0.35 \mu \mathrm{g} \mathrm{L}{ }^{-1}$ was recorded at Chumbe. The concentration of nitrate differed significantly among the four sampled sites $(\mathrm{H}=26.016, \mathrm{df}=3, \mathrm{p}<0.001)$. Nitrate levels at Bawe were significantly higher than those at Mnemba $(U=439.000, \mathrm{p}=0.018)$ and Pongwe $(U=246.500$, $\mathrm{p}<0.001)$. Equally, Chumbe had significantly higher nitrate concentration than Mnemba $(U=469.500, \mathrm{p}=0.044)$ and Pongwe $(U=314.500, \mathrm{p}<0.001)$. Mnemba had statistically higher nitrate concentration than Pongwe $(U=397.000, \mathrm{p}=0.005)$. However, Bawe and Chumbe had statistically similar nitrate concentrations $(U=641.500, \mathrm{p}=0.942)$. The spatial concentration of nitrate decreased significantly as the distance of the sampling site increased from Unguja town $(r=-0.279, \mathrm{p}=0.001)$.

\section{Phytoplankton composition}

A total of 72 phytoplankton species belonging to four families were identified at the four coral reef sites during the entire 12 months of the study period. Bacillariophyceae was the most dominant phytoplankton class with 51 species representing $70.83 \%$ (Fig. 4).

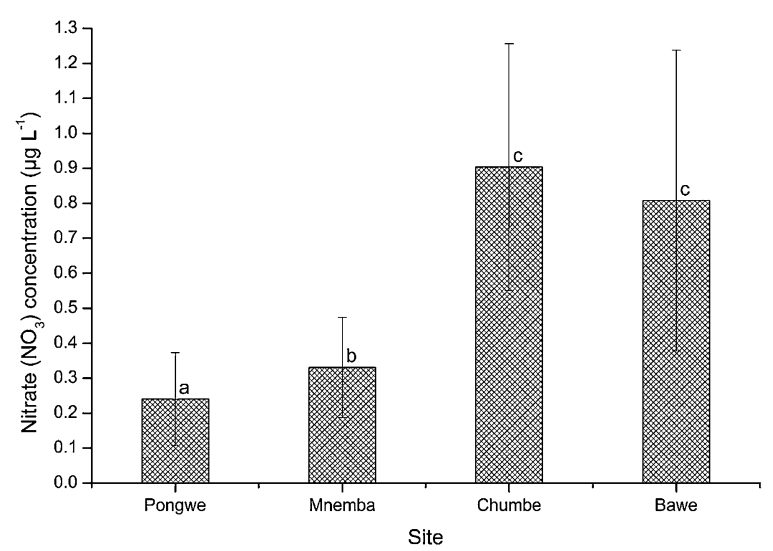

Fig. 3 The spatial variations in nitrate $\left(\mathrm{NO}_{3}\right)$ concentration at the four sites during the study period. Different letters $(a, b$ and $c)$ above bars indicate significant differences $(p \leq 0.05)$ 
Bacillariophyceae

Dictyochophyceae

Cyanophyceae

Dinophyceae

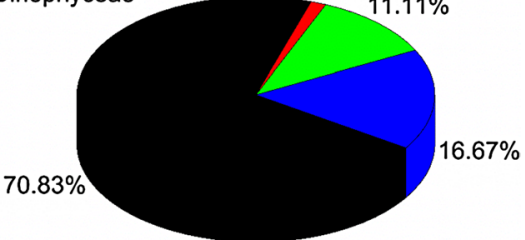

Fig. 4 Phytoplankton composition from all four coral reef sites during the entire year of study

The most dominant species of Bacillariophyceae were Rhizosolenia sp., Nitzschia sp., Chaetoceros sp., Bacteriastrum sp. and Navicula sp. Dinophyceae was the second dominant group with 12 species representing $16.67 \%$. It was dominated by Ceratium sp., Dinophysis sp., Protoperidinium sp. and Prorocentrum sp. Cyanophyceae had $11.11 \%$ represented by Oscillatoria sp., Nostoc sp., Schizothrix sp. and Johannesbaptistia pellucida. Dictyocha fibula was the only species in the group of Dictyochophyceae (1.39\%) identified at Chumbe.

All the four coral reef sites had identical types of phytoplankton species. The Shannon equitability values were $0.86,0.84,0.83$ and 0.82 for Chumbe, Pongwe, Mnemba and Bawe, respectively. Chumbe Island recorded relatively the highest number of species (57). The other sites had similar number of phytoplankton species, i.e., 47, 48 and 49 for Pongwe, Bawe and Mnemba, respectively. Furthermore, regardless of the study site, the dominant group was Bacillariophyceae, which had more number of species that occurred throughout the year. The Shannon-Weaver diversity indices were 3.67, 3.60, 3.55 and 3.49 for Chumbe, Pongwe, Mnemba and Bawe, respectively.

\section{Chlorophyll a concentration}

The minimum and maximum mean values of chlorophyll $a$ concentrations were $0.33 \pm 0.04$ and $0.47 \pm 0.07 \mathrm{mg} \mathrm{L}^{-1}$ recorded at Chumbe and Bawe, respectively (Fig. 5). The spatial variations in chlorophyll $a$ concentration was significantly different among the four sampled sites $(\mathrm{H}=11.844, \mathrm{df}=3, \mathrm{p}=0.008)$. Significantly higher chlorophyll a concentration was recorded at Bawe than at Mnemba $(U=422.000, \mathrm{p}=0.011)$ and Chumbe $(U=384.500, \mathrm{p}=0.003)$. Pongwe had significant higher chlorophyll $a$ concentration than Chumbe $(U=463.000, \mathrm{p}=0.037)$ and marginally with Mnemba $(U=477.000, \mathrm{p}=0.054)$. However, insignificant difference in chlorophyll $a$ concentration existed between Bawe and Pongwe $(U=602.000, \mathrm{p}=0.604)$. Mnemba and Chumbe sites showed statistically similar chlorophyll $a$ concentrations $(U=646.000, \mathrm{p}=0.982)$. The spatial concentration of chlorophyll $a$ decreased significantly as the distance of the sampling site increased from Unguja town $(r=-0.245, \mathrm{p}=0.003)$.

\section{Temporal variations}

Water quality parameters

Salinity showed heterogeneous temporal variation with a minimum value of $32.00 \pm 1.43$ ppt recorded in August 2008 (Fig. 6). The maximum value (around 36 ppt) was 


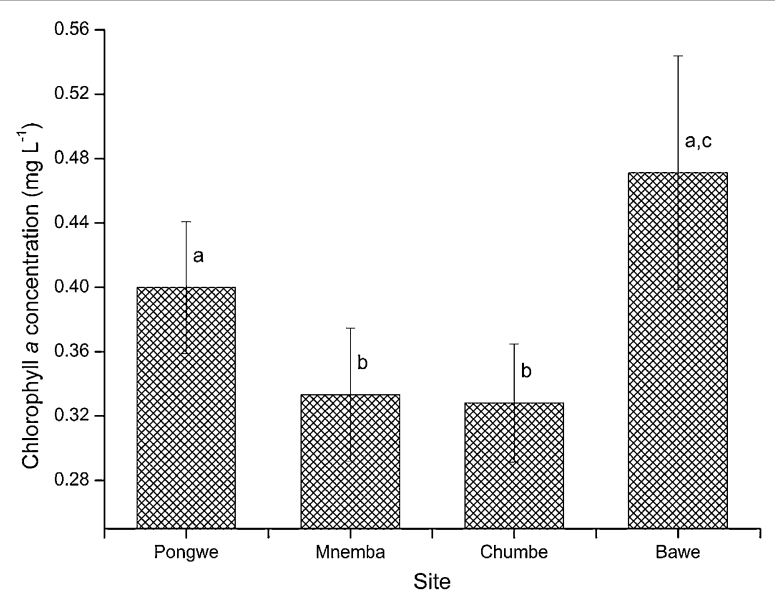

Fig. 5 The spatial variations in chlorophyll a concentration at the four sites during the study period. Different letters $(a, b$ and $c)$ above bars indicate significant differences $(p \leq 0.05)$

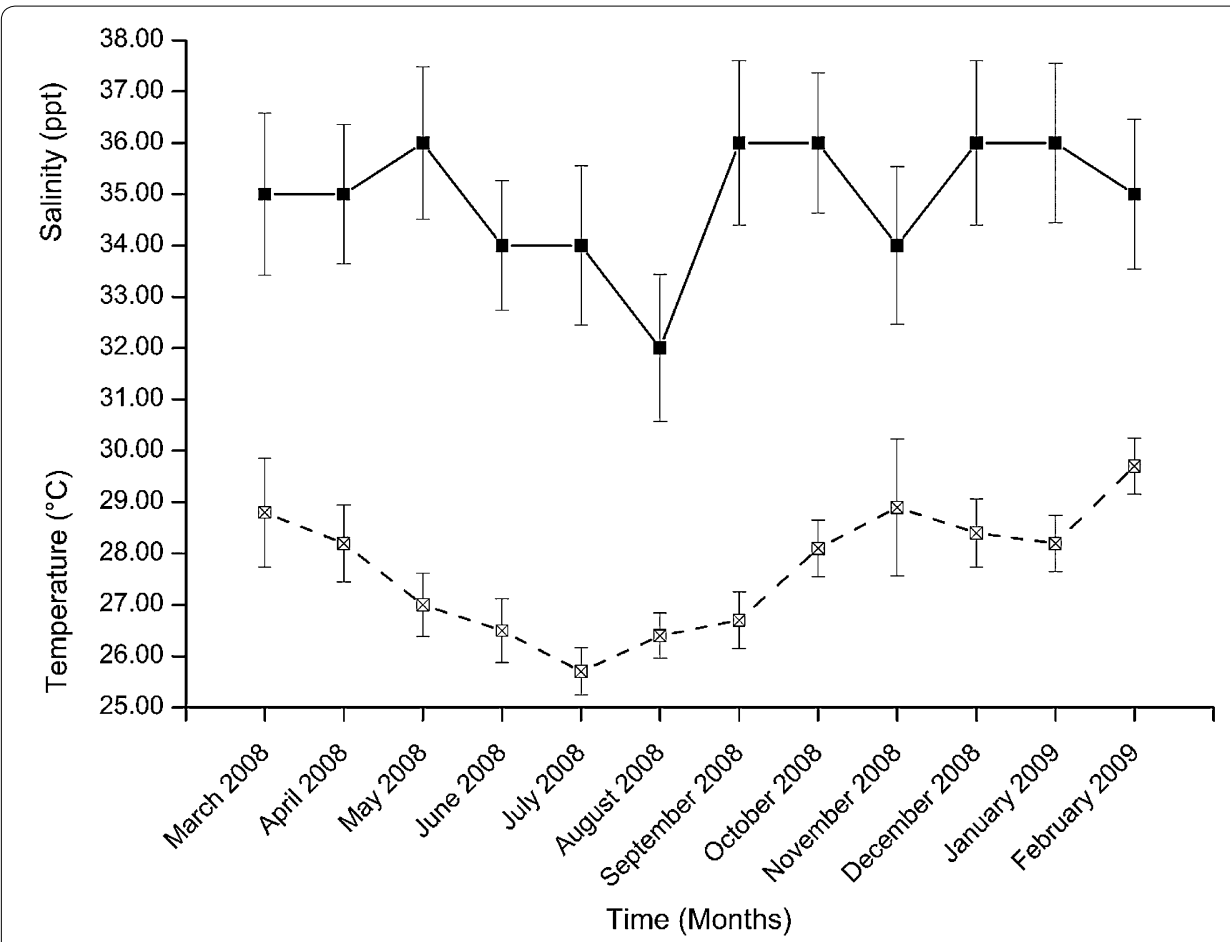

Fig. 6 Temporal variation in mean values $( \pm S D$ ) of salinity and water temperature during the study period

recorded in 5 months. Salinity was significantly different among the sampling months $(\mathrm{H}=21.569, \mathrm{df}=11, \mathrm{p}=0.028)$. The salinity values in August was significantly lower than that in March, April, May, September, October and December (2008), as well as in January and February (2009) ( $\mathrm{p}<0.05)$.

Water temperature showed a regular seasonal cycle (Fig. 6). The maximum water temperature was recorded in February $2009\left(29.70 \pm 0.55{ }^{\circ} \mathrm{C}\right)$ and the minimum was in July $2008\left(25.70 \pm 0.46^{\circ} \mathrm{C}\right)$. Water temperature differed significantly 
among the sampling months $\left(\mathrm{F}_{11,96}=89.545, \mathrm{p}<0.001\right)$. February 2009 had significantly the highest water temperature of all the months $(\mathrm{p}<0.05)$. On the other hand, July 2008 had significantly the lowest water temperature of all the months $(\mathrm{p}<0.05)$.

The results of dissolved oxygen and $\mathrm{pH}$ are shown in Fig. 7. While dissolved oxygen decreased with time (from August 2008 onwards), $\mathrm{pH}$ tended to increase within the same period. Nevertheless, all the dissolved oxygen values were above $5.0 \mathrm{mg} \mathrm{L}^{-1}$ and $\mathrm{pH}$ values remained alkaline for all months. The highest $\mathrm{pH}$ value $(8.05 \pm 0.04)$ was obtained in October 2008 and January 2009. The lowest value $(7.68 \pm 0.07)$ was recorded in May 2008. The values of $\mathrm{pH}$ varied significantly among the sampling months $(\mathrm{H}=34.079, \mathrm{df}=11, \mathrm{p}<0.001)$. The $\mathrm{pH}$ values for May, June and September 2008 were significantly lower than the rest of the months $(\mathrm{p}<0.05)$. However, no significant difference in water $\mathrm{pH}$ was recorded between March and April, July and August 2008 as well as between February 2009 and October 2008 and January 2009 (p > 0.05). Equally, November and December 2008 had statistically similar values of water $\mathrm{pH}(\mathrm{p}>0.05)$. The highest dissolved oxygen $\left(6.35 \pm 0.06 \mathrm{mg} \mathrm{L}^{-1}\right)$ was observed in April 2008 whereas the lowest $\left(5.18 \pm 0.03 \mathrm{mg} \mathrm{L}^{-1}\right)$ was recorded in February 2009. Dissolved oxygen differed significantly among the sampling months $(\mathrm{H}=34.784, \mathrm{df}=11, \mathrm{p}<0.001)$. All the measured dissolved oxygen values differed significantly among the sampling months $(\mathrm{p}<0.05)$.

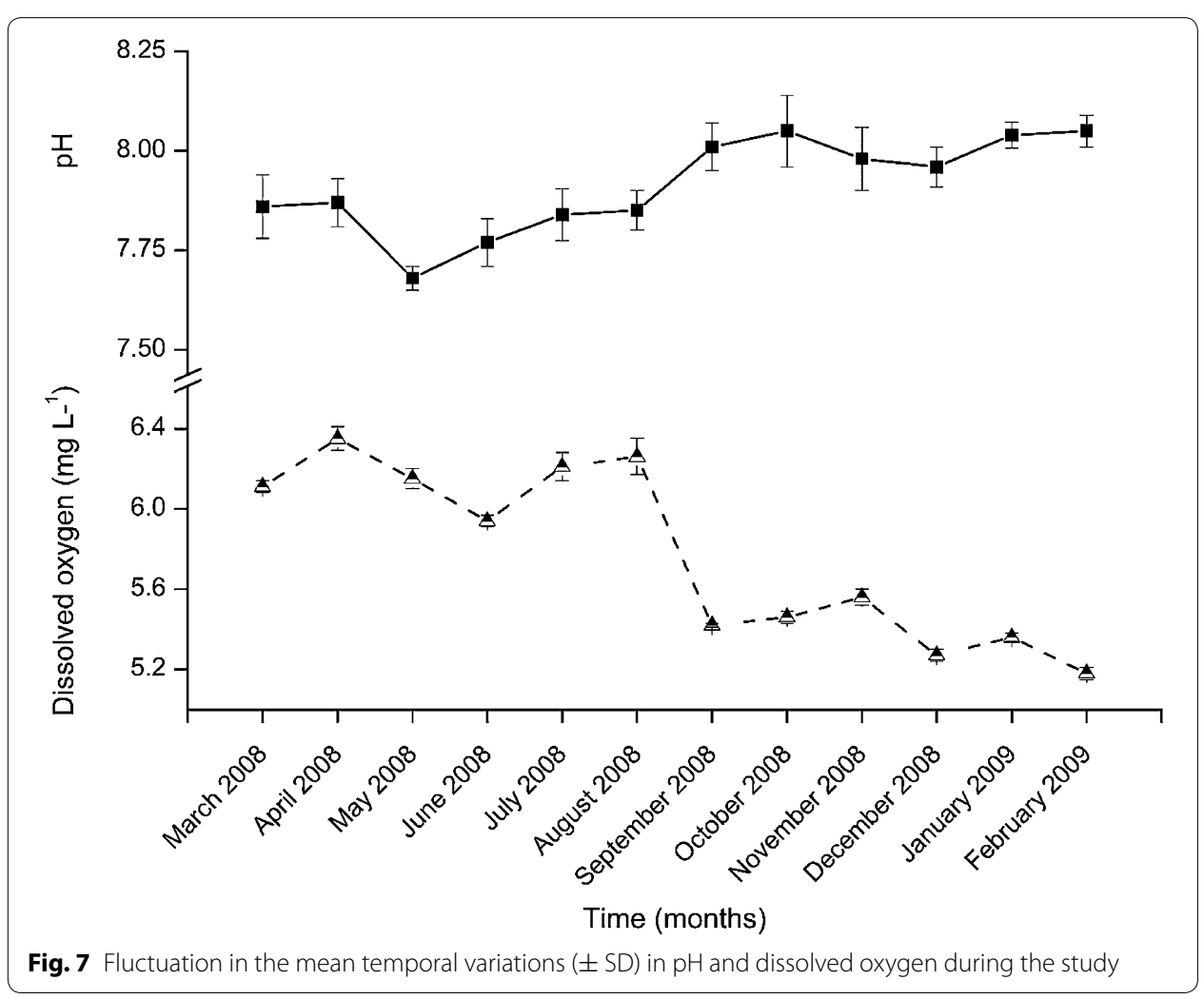




\section{Nutrients concentration}

The values of phosphate concentration varied between $0.25 \pm 0.20$ and $1.43 \pm 0.60 \mu \mathrm{g} \mathrm{L}^{-1}$ recorded in December and July 2008, respectively (Fig. 8). The concentration indicated a significant seasonal trend among the sampling months $(\mathrm{H}=23.705, \mathrm{df}=11, \mathrm{p}=0.014)$. On one hand, the phosphate concentration recorded in July 2008 was significantly higher than that recorded in April, May, June, August, October, November, December 2008 and February 2009 ( $<<0.05$ ). Similarly, January 2009 had significantly higher phosphate concentration than August, November, December 2008 and February 2009 ( $p<0.05$ ). On the other hand, the phosphate concentration recorded in December 2008 was significantly lower than that recorded in March, April, May, June, September, October, 2008 and January 2009 ( $\mathrm{p}<0.05$ ). The phosphate concentration recorded in February 2009 was significantly lower than that recorded in March, April, May, September, October and November 2008 ( $\mathrm{p}<0.05)$.

The values of nitrate concentration varied between $0.21 \pm 0.07$ and $1.78 \pm 1.63 \mu \mathrm{g} \mathrm{L}-1$ recorded in December and March 2008, respectively (Fig. 9). Nitrate concentration indicated significant temporal variation among the different sampling months $(\mathrm{H}=48.993$, $\mathrm{df}=11, \mathrm{p}<0.001)$. The nitrate concentration recorded in March 2008 was significantly higher than that recorded in November and December 2008 as well as January and February 2009 ( $\mathrm{p}<0.05$ ). Equally, the nitrate concentrations recorded in the months of April, May and June 2008 were significantly higher than those recorded in August, September, October, November and December 2008 as well as January and February 2009 $(\mathrm{p}<0.05)$.

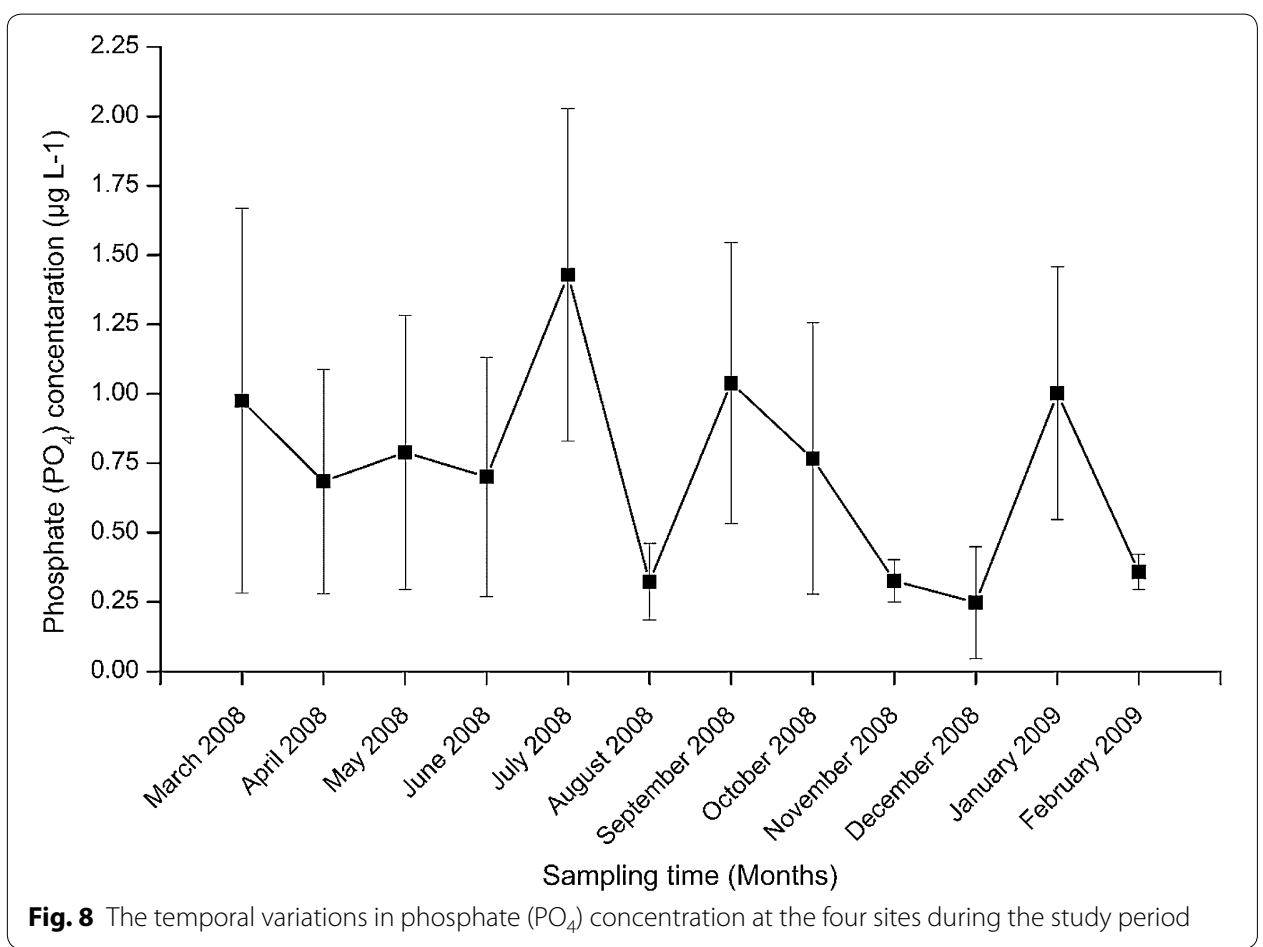




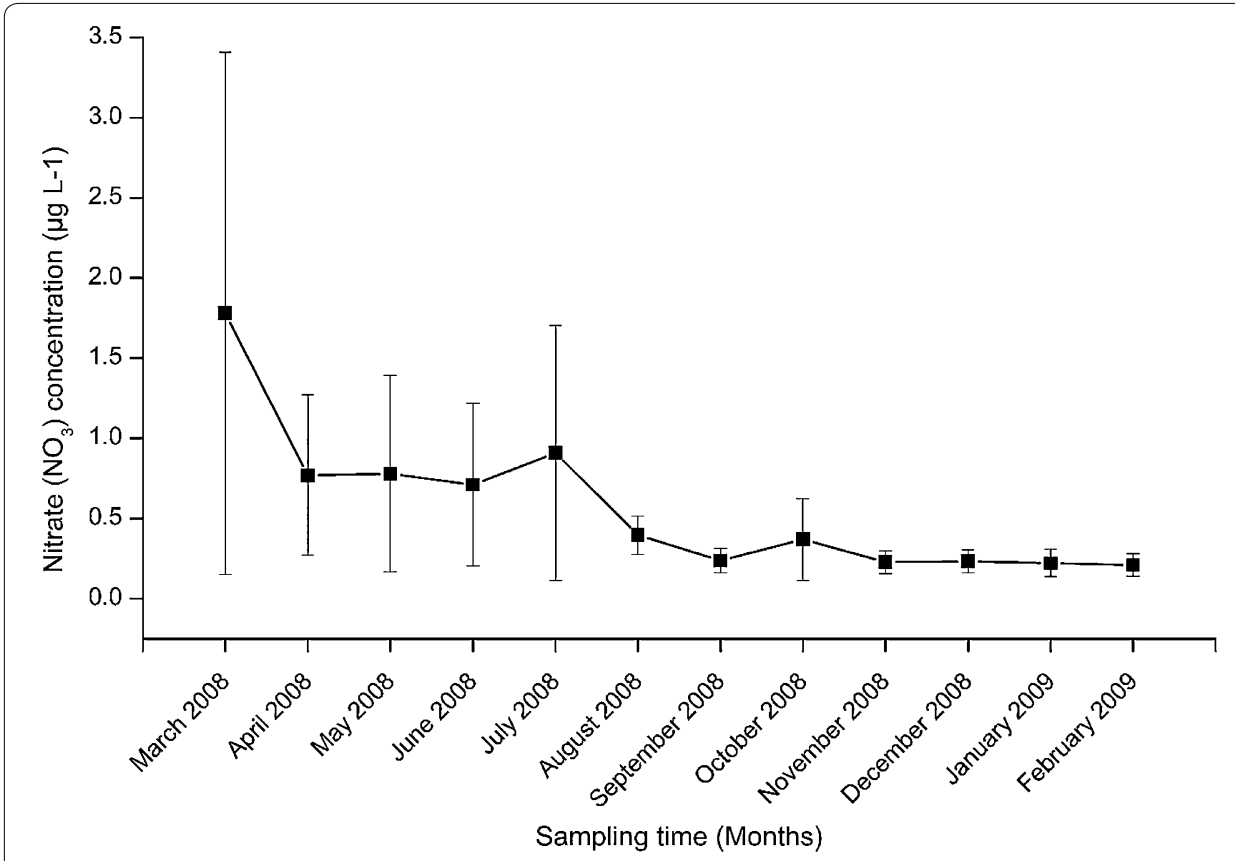

Fig. 9 The temporal variations in nitrate $\left(\mathrm{NO}_{3}\right)$ concentration at the four sites during the study period

\section{Phytoplankton composition}

The temporal distribution of phytoplankton showed that Rhizosolenia sp. were abundant in all the sampling months except July 2008. Oscillatoria sp. were abundant during the months of March, April, October and December, 2008; and also in January and February 2009. Nitzschia sp., Chaetoceros sp. and Bacteriastrum sp. were abundant in the months from July 2008 to February 2009 and Ceratium sp. were abundant in the later months, from September 2008 to February 2009. Navicula sp. were abundant in August, September 2008 and January and February 2009. Dinophysis sp. were abundant only in December 2008 and February 2009. Nostoc sp., were abundant in July and December 2008, January and February 2009. Protoperidinium sp. and Schizothrix sp. were abundant in September 2008 whereas Johannesbaptistia pellucida were abundant only in July 2008.

\section{Chlorophyll a concentration}

The temporal variation in chlorophyll $a$ concentration during the twelve months of sampling period are shown in Fig. 10. The mean chlorophyll $a$ concentration was below detection limit during the month of March 2008. There were two peaks in chlorophyll a concentration recorded in the months of July $2008\left(0.64 \pm 0.38 \mathrm{mg} \mathrm{L}^{-1}\right)$ and January $2009\left(0.68 \pm 0.08 \mathrm{mg} \mathrm{L}^{-1}\right)$. Sampling months had significant difference in chlorophyll a concentration $(\mathrm{H}=25.358, \mathrm{df}=11, \mathrm{p}=0.008)$. The concentration of chlorophyll $a$ recorded in March 2008 was significantly lower than that recorded in all other months. The concentration of chlorophyll $a$ recorded in April 2008 was significantly higher than that recorded in May, October, November and December 2008 ( $\mathrm{p}<0.05)$. Similarly, the months of July 2008 and January 2009 had significantly higher chlorophyll $a$ concentration than May, June, August, October, November and December 2008 ( $\mathrm{p}<0.05)$. 


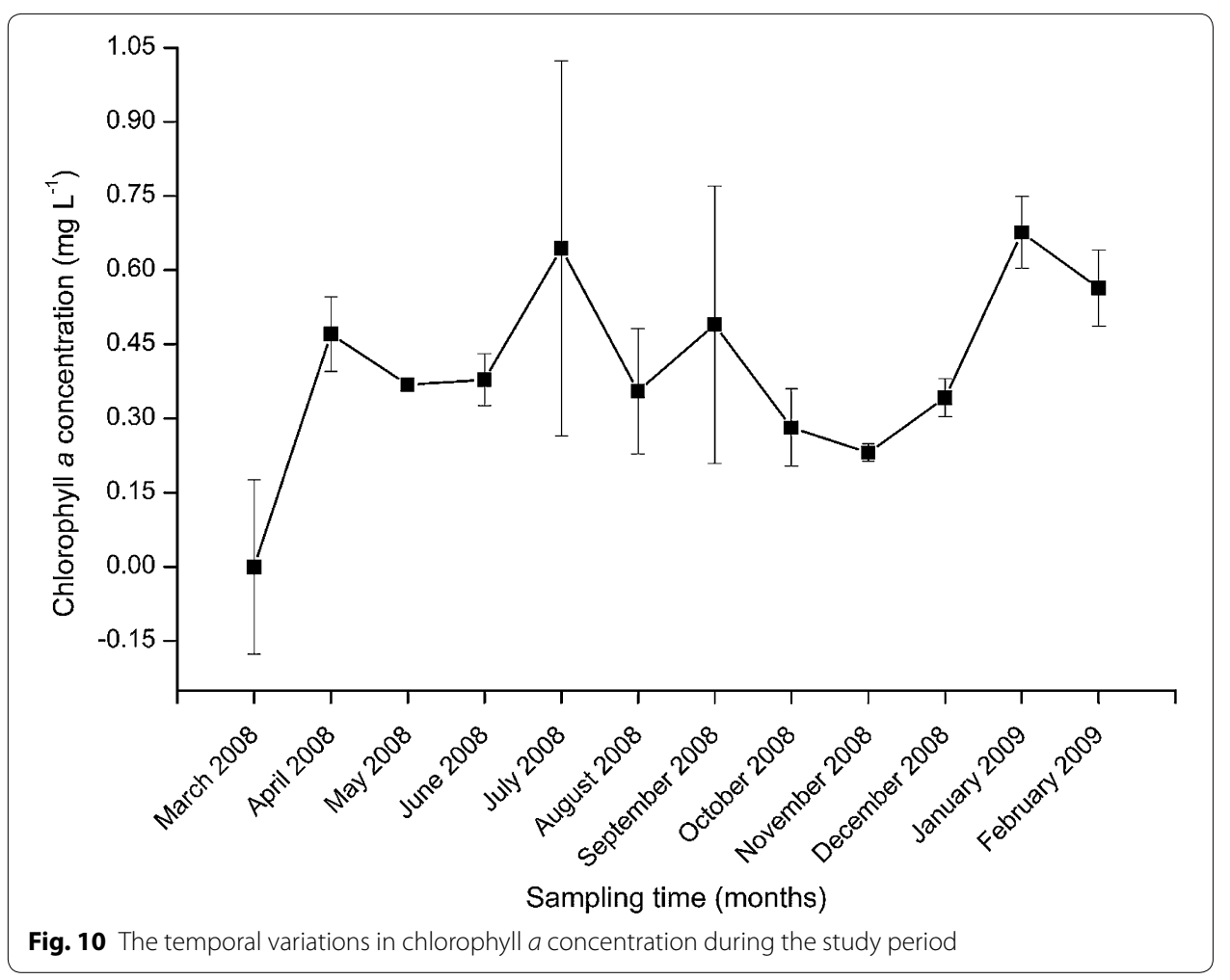

The month of February 2009 also had significantly higher chlorophyll $a$ concentration than months of October, November and December $2008(\mathrm{p}<0.05)$.

\section{The relationship between chlorophyll $a$ concentration, water quality parameters and nutrients}

The results of temporal correlation between chlorophyll $a$ concentration and water quality parameters revealed positive and negative influence. Dissolved oxygen had a positive significant correlation with chlorophyll $a$ concentration $(\mathrm{r}=0.68, \mathrm{p}=0.044)$. Temperature $(\mathrm{r}=-0.036, \mathrm{p}=0.667)$ and salinity $(\mathrm{r}=-0.011, \mathrm{p}=0.893)$ had negative insignificant correlation with chlorophyll $a$ concentration while $\mathrm{pH}(\mathrm{r}=0.056, \mathrm{p}=0.507)$ had positive insignificant correlation.

The concentration of chlorophyll $a$ had significant positive correlations with the concentrations of phosphate $(\mathrm{r}=0.216, \mathrm{p}=0.009)$ and nitrate $(\mathrm{r}=0.250, \mathrm{p}=0.003)$. The concentration of phosphate and nitrate also significantly positively correlated $(r=0.710, p<0.001)$.

\section{Discussion}

This study aimed to determine the spatial and seasonal variability in water quality variables and nutrients relative to phytoplankton community structure, diversity and biomass in order to indirectly provide insights on the health status of coral reefs in Unguja Island. The nutrient concentration results revealed significant higher phosphate concentration at Bawe than at Chumbe, Mnemba and Pongwe. Similarly, nitrate was also significantly higher at Bawe and Chumbe than at Mnemba and Pongwe. Moreover, results showed that the concentrations of phosphate and nitrate decreased as the sampling site distance 
increased from Unguja town. These results are in agreement with those obtained by Bjork et al. (1995). This is due to the influence of domestic sewage inflows from Unguja town to Bawe site. Bawe is the closest site from Unguja town, located at about $6.33 \mathrm{~km}$ only compared to $13.20 \mathrm{~km}$ for Chumbe, $53.00 \mathrm{~km}$ for Mnemba and $33.30 \mathrm{~km}$ for Pongwe. Due to its proximity to Unguja town, more domestic sewage water from households and hotels in the town released into the ocean find their way to the site thereby increasing the concentration of nutrients.

Despite the higher concentrations of phosphate and nitrate at Bawe, its coral reefs are considered health because the levels of nutrients for unhealthy coral reef ecosystems are approximately $3 \mathrm{mg} \mathrm{L}^{-1}$ of $\mathrm{P}$ as orthophosphate and organophosphate and $14 \mathrm{mg} \mathrm{L}^{-1}$ of $\mathrm{N}$ as nitrate (Bell 1992; Goreau and Thacker 1994). These levels are still higher compared to highest concentrations of $1.45 \pm 0.23 \mu \mathrm{g} \mathrm{L}^{-1}$ for phosphate and $0.90 \pm 0.16 \mu \mathrm{g} \mathrm{L}^{-1}$ for nitrate recorded in the present study. However, release of nutrients in the coral reefs should be limited to avoid excessive growth of phytoplankton and macroalgae, which may affect the growth of coral reefs by competing for light, nutrients and space or even through development of harmful algal blooms (HBAs) in the case of phytoplankton.

The current study showed dominance of phytoplankton by Bacillariophyceae class (70.83 \%). Similar results in marine environment have been obtained by Saravanakumar et al. (2008), Saifullah et al. (2014) and Moto (2015) who obtained 78.85, 76.40 and $67.69 \%$ of Bacillariophyceae composition, respectively. The high abundance of Bacillariophyceae is due to their ability to proliferate in the aquatic environment. Bacillariophyceae have been shown to exhibit a boom and bust (or bloom and bust) lifestyle in freshwater and marine environments (Richard and Stickley 2010). They effectively utilize nutrients and light availability to allow them compete and quickly dominate the other phytoplankton species (Buchan et al. 2014). Based on this capability, Furnas (1990) classified them as opportunistic r-strategists (i.e. those organisms whose ecology is defined by a high growth rate, $r$ ). This ability make Bacillariophyceae the most abundant and ubiquitous group in terms of ecosystems and water chemistry (Coelho et al. 2013; Desrosiers et al. 2013) making them responsible for approximately $20 \%$ of global aquatic photosynthesis (Rosenwasser et al. 2014). The dominance of Bacillariophyceae in coral reefs as obtained in the present study is likely to contribute to nutrient cycling and gas exchange (Barott et al. 2011) subsequently promoting growth and abundance of corals and algae.

Dinophyceae ranked second in dominance representing 16.67 \% dominated by Ceratium sp., Dinophysis sp., Protoperidinium sp. and Prorocentrum sp. while Cyanophyceae was the third group (11.11 \%) represented by Oscillatoria sp., Nostoc sp., Schizothrix sp. and Johannesbaptistia pellucida. These results are similar to those obtained by Bajarias (2000) working in the South China Sea; Dayala et al. (2014) at Cochin estuarine and Moto (2015) in Zanzibar waters in the Indian Ocean. Dinophyceae are known to form symbiotic relationship with coral reefs enabling them to flourish in coral reef sites than other phytoplankton species (Hackett et al. 2004). In this relationship, Dinophyceae symbionts play a significant role in the nutrition of coral reefs and physiology by translocating enough photosynthetically fixed carbon to meet the hosts' respiratory demands. Meanwhile, they facilitate the assimilation and conservation of nitrogen (Santos et al. 2004) while getting enough carbon for photosynthesis allowing them to multiply and 
increase in number (Badylak and Phlips 2004). The symbiont diversity has also shown to help coral reefs survive moderate climate change (Baskett et al. 2009).

The general ecological implications of the composition of phytoplankton species obtained at the four sites during the entire 12 months of the study period indicate existence of potentially harmful microalgae. Some of the Dinophyceae, Cyanophyceae and Dictyochophyceae species identified in the present study are known to produce toxins and affect fish species. Ceratium sp., Dinophysis sp., Protoperidinium sp. and Prorocentrum sp. were reported by Siyambalapitiya et al. (2012) as potentially harmful red tide forming Dinophyceae. Protoperidinium sp. was identified as the causative agent of a group of toxins known as azaspiracids (James et al. 2003; Blanco et al. 2005). High abundance of certain species of Cyanophyceae such as Oscillatoria sp. has been shown to produce microcystins toxins (Kyewalyanga and Lugomela 1999) and are associated with aquatic pollution (Ekwu and Sikoki 2006). Dictyocha fibula, a Dictyochophyceae species has been shown to be harmful to fish gills at high concentrations (Koutsodendris et al. 2015). Based on the present study, the four sites have low nutrients but bear a problem of existence of toxic phytoplankton species. Although the concentration is somehow low, it is hereby suggested that frequent monitoring programs need to be conducted to ensure that the consumption of seafood from the studied areas does not lead to health problems.

The spatial variations in chlorophyll $a$ concentration during the study indicated higher amount at Bawe. The results further showed that, the concentration of chlorophyll $a$ was significantly positively correlated with phosphate and nitrate. Higher chlorophyll $a$ concentration at Bawe is most likely due to higher concentration of phosphate and nitrate. Studies in oceans have shown that the biomass of phytoplankton (indirectly measured using chlorophyll $a$ ) is limited by phosphate and nitrate (Tantanasarit et al. 2013; Turner and Rabalais 2013). Consequently, since Bawe had higher levels of both phosphate and nitrate, it resulted in higher concentration of chlorophyll $a$. Most chlorophyll $a$ values obtained in the present study are not worrisome because they have not reached the eutrophication threshold value at or below an annual mean of $0.5 \mathrm{mg} \mathrm{m}^{-3}$ as suggested by Bell (1992). However, a mean value of $0.47 \pm 0.04 \mathrm{mg} \mathrm{L}^{-1}$ obtained at Bawe provides a warning signal to reduce the release of un-treated sewage water into the ocean.

The current results showed peak chlorophyll $a$ concentration in July 2008 and January 2009 during the long monsoon winds. Similar results of higher chlorophyll $a$ concentration during monsoon winds have been obtained by Strutton et al. (2015). Several recent studies in main land Tanzanian and Zanzibar waters (Peter 2013; Ezekiel 2014; Moto 2015) have also revealed higher chlorophyll $a$ during the months of July and January due to the influence of southeast monsoon winds. During monsoon season, strong wind mixing brings up nutrient-rich waters from deep waters to the surface, thereby stimulating phytoplankton growth and production.

The current study indicated that, dissolved oxygen had a positive significant correlation with chlorophyll $a$ concentration whereas $\mathrm{pH}$, temperature and salinity were all negatively correlated. Negative correlation between chlorophyll $a$ concentration and salinity has been reported by Macedo et al. (2001) and Yin (2002), pH by Rahaman et al. (2013) and temperature by Dayala et al. (2014) similar to the results obtained in this study. The positive correlation between chlorophyll $a$ concentration and dissolved oxygen is due to 
necessity of the latter for phytoplankton biogeochemical processes. Dissolved oxygen is one of the most important water quality parameters for phytoplankton health because of its influence in a number of biogeochemical processes such as respiration and metabolism that affect their life (Iriarte et al. 2015). During photosynthesis process, oxygen is released as a byproduct, thus as phytoplankton biomass increases (as determined by chlorophyll $a$ concentration), the rate of photosynthesis also increases releasing more oxygen into the water. This phenomenon is beneficial to the coral reefs at the four studied sites.

\section{Conclusion}

The current results indicated dominance of Bacillariophyceae and Dinophyceae both spatially and temporally in coral reefs. These results imply that, at present state phytoplankton are likely to contribute to nutrient cycling and gas exchange for the benefit of both corals and algae. However, release of nutrients in the coral reefs should be limited to avoid excessive growth of Dinophyceae (most of which are potentially harmful microalgae), Bacillariophyceae and possibly macroalgae that may compete with the host symbiotic algae for nutrients, light and inorganic carbon affecting the development of coral reefs. Spatially, the coral reefs sites at the moment have low nutrient levels and are in good health. Temporally, chlorophyll $a$ concentration at the four coral reef sites is regulated by the availability of phosphate, nitrate and dissolved oxygen as well as monsoon winds. The existence of toxic phytoplankton species at the four coral reef sites calls for regular monitoring programmes on HABs and careful consumption of the associated seafood. The higher spatial chlorophyll $a$ concentration at Bawe compared to other sites demands for mechanisms in Unguja Island to limit the release of domestic sewage from households and hotels to safeguard the coral reefs at the island. The present study provides a baseline guide on the status of coral reefs by using phytoplankton and nutrients for one year. This study should be followed by extensive study covering all the existing coral reefs sites in coastal waters of Tanzania for longer periods of time.

Authors' contributions

SML conceived, designed the study, collected and analysed data and drafted the manuscript: MSK conceived, designed the study, collected and analysed data. All authors read and approved the final manuscript.

\section{Author details}

${ }^{1}$ Department of Aquatic Sciences and Fisheries, University of Dar es Salaam, P.O. Box 35064, Dar es Salaam, Tanzania. 2 Department of Biology, School of Life Sciences, Laboratory of Aquaculture Nutrition and Environmental Health, East China Normal University, 500 Dong Chuan Road, Shanghai 200241, China. ${ }^{3}$ Institute of Marine Sciences, University of Dar es Salaam, Mizingani Road, P.O. Box 668, Zanzibar, Tanzania.

\section{Acknowledgements}

We are greatly thankful to The Global Environment Facility (GEF) for funding this work through the Coral Reef Targeted Research and Capacity Building for Management (CRTR) project. We are extremely thankful to Dr. Salim M. Mohammed and Dr. Musa Chacha (currently Dr. Chacha is at the Nelson Mandela African Institute of Science and Technology) from the Institute of Marine Sciences (IMS) of the University of Dar es Salaam (UDSM) for sharing nutrients data. Special recognition to Mr. Mtumwa Mwadini and Ms. Khayrat Ubwa for their invaluable technical help on data collection and identification of phytoplankton species and nutrients analysis, respectively. IMS and UDSM are acknowledged for granting permission for authors to participate in the study. We are grateful to two anonymous reviewers whose comments and suggestions improved our manuscript.

Competing interests

The authors declare that they have no competing interests. 


\section{References}

Alvain S, Moulin C, Dandonneau Y, Loisel H (2008) Seasonal distribution and succession of dominant phytoplankton groups in the global ocean: a satellite view. Global Biogeochem Cy 22(3):1-15

Badylak S, Phlips EJ (2004) Spatial and temporal patterns of phytoplankton composition in subtropical coastal lagoon, the Indian River Lagoon, Florida, USA. J Plankton Res 26(10):1229-1247

Bajarias FFA (2000) Phytoplankton in the surface layers of the South China Sea, Area III: Western Philippines. In: Proceedings of the 3rd Technical Seminar on Marine Fisheries Resources Survey in the South China, Sea Area III, Western Philippines SEAFDEC. Bangkok, pp 197-216

Barott KL, Rodriguez-Brito B, Janouškovec J, Marhaver KL, Smith JE, Keeling P, Rohwer FL (2011) Microbial diversity associated with four functional groups of benthic reef algae and the reef-building coral Montastraea annularis. Environ Microbiol 13(5):1192-1204

Baskett ML, Gaines SD, Nisbet RM (2009) Symbiont diversity may help coral reefs survive moderate climate change. Ecol Appl 19(1):3-17

Bell P (1992) Eutrophication and coral reefs-some examples in the Great Barrier Reef lagoon. Water Res 26(5):553-568

Bergman KC, Öhman MC, Svensson S (2000) Influence of habitat structure on Pomacentrus sulfureus, a western Indian Ocean reef fish. Environ Biol Fishes 59(3):243-252

Bjork M, Mohammed SM, Bjorklund M, Semesi A (1995) Coralline algae, important coral reef builders threatened by pollution. Ambio 24(7-8):502-505

Blanco J, Moroño Á, Fernández ML (2005) Toxic episodes in shellfish, produced by lipophilic phycotoxins: an overview. Galician J Mar Resour 1:1-70

Bronstein O, Loya Y (2014) Echinoid community structure and rates of herbivory and bioerosion on exposed and sheltered reefs. J Exp Mar Biol Ecol 456:8-17

Buchan A, LeCleir GR, Gulvik CA, Gonzalez JM (2014) Master recyclers: features and functions of bacteria associated with phytoplankton blooms. Nat Rev Micro 12(10):686-698

Coelho SM, Simon N, Ahmed S, Cock JM, Partensky F (2013) Ecological and evolutionary genomics of marine photosynthetic organisms. Mol Ecol 22(3):867-907

Dayala V, Salas P, Sujatha C (2014) Spatial and seasonal variations of phytoplankton species and their relationship to physicochemical variables in the Cochin estuarine waters, Southwest coast of India. Indian J Mar Sci 43:937-947

De'ath G, Fabricius KE, Sweatman H, Puotinen M (2012) The 27-year decline of coral cover on the Great Barrier Reef and its causes. Proc Natl Acad Sci 109(44):17995-17999

Desrosiers C, Leflaive J, Eulin A, Ten-Hage L (2013) Bioindicators in marine waters: benthic diatoms as a tool to assess water quality from eutrophic to oligotrophic coastal ecosystems. Ecol Indicators 32:25-34

Ekwu A, Sikoki F (2006) Phytoplankton diversity in the Cross River estuary of Nigeria. J Appl Sci Environ Manage 10(1):89-95

Ezekiel J (2014) Temporal and spatial variation of phytoplankton in Rufiji Delta/Mafia Channel, Southern Tanzania. M.Sc. Thesis, University of Dar es Salaam, Dar es Salaam, Tanzania, pp 99

Furnas MJ (1990) In situ growth rates of marine phytoplankton: approaches to measurement, community and species growth rates. J Plankton Res 12(6):1117-1151

Goreau TJ, Thacker K (1994) Coral reefs, sewage, and water quality standards. In: Proceedings of the Third Annual Conference, Caribbean Water and Wastewater Association. Kingston, Jamaïque, pp 98-117

Gössling S (2001) The consequences of tourism for sustainable water use on a tropical island: Zanzibar, Tanzania. J Environ Manag 61(2):179-191

Hackett JD, Anderson DM, Erdner DL, Bhattacharya D (2004) Dinoflagellates: a remarkable evolutionary experiment. Am J Bot 91(10):1523-1534

Henderson PA, Seaby RMH (2001) Species diversity and richness 2.65. Pisces Conservation Ltd, Pennington, Lymington

Iriarte A, Villate F, Uriarte I, Alberdi L, Intxausti L (2015) Dissolved oxygen in a temperate estuary: the Influence of hydroclimatic factors and eutrophication at seasonal and inter-annual time scales. Estuar Coasts 38(3):1000-1015

James KJ, Moroney C, Roden C, Satake M, Yasumoto T, Lehane M, Furey A (2003) Ubiquitous 'benign'alga emerges as the cause of shellfish contamination responsible for the human toxic syndrome, azaspiracid poisoning. Toxicon 41(2):145-151

Johnstone RW, Muhando CA, Francis J (1998) The status of the coral reefs of Zanzibar: one example of a regional predicament. Ambio 27(8):700-707

Koutsodendris A, Brauer A, Zacharias I, Putyrskaya V, Klemt E, Sangiorgi F, Pross J (2015) Ecosystem response to humanand climate-induced environmental stress on an anoxic coastal lagoon (Etoliko, Greece) since 1930 AD. J Paleolimnol 53(3):255-270

Kyewalyanga M, Lugomela C (1999) Existence of potentially harmful microalgae in coastal waters around Zanzibar: a need for a monitoring programme. In: Proc of the Anniversary Conferences on Advances in Marine Science in Tanzania, pp 319-328

Lange G-M, Jiddawi N (2009) Economic value of marine ecosystem services in Zanzibar: implications for marine conservation and sustainable development. Ocean Coast Manage 52(10):521-532

Lugomela C, Wallberg P, Nielsen TG (2001) Plankton composition and cycling of carbon during the rainy season in a tropical coastal ecosystem, Zanzibar, Tanzania. J Plankton Res 23(10):1121-1136

Macedo MF, Duarte P, Mendes P, Ferreira JG (2001) Annual variation of environmental variables, phytoplankton species composition and photosynthetic parameters in a coastal lagoon. J Plankton Res 23(7):719-732

Masalu DC (2000) Coastal and marine resource use conflicts and sustainable development in Tanzania. Ocean Coast Manage 43(6):475-494

Mbije NE, Wagner GM, Francis J, Öhman MC, Garpe K (2002) Patterns in the distribution and abundance of hard corals around Zanzibar Island. Ambio J Hum Environ $31(7): 609-611$

McClanahan TR, Ateweberhan M, Muhando CA, Maina J, Mohammed MS (2007) Effects of climate and seawater temperature variation on coral bleaching and mortality. Ecol Monogr 77(4):503-525

Moberg F, Folke C (1999) Ecological goods and services of coral reef ecosystems. Ecol Econ 29(2):215-233 
Mohammed SM (2002) Pollution management in Zanzibar: the need for a new approach. Ocean Coast Manage 45(4-5):301-311

Moto EA (2015) Seasonal variability of phytoplankton diversity and biomass in the coastal waters off Zanzibar. Ph.D. Thesis, University of Dar es Salaam, Dar es Salaam, Tanzania, pp 230

Moynihan MA, Baker DM, Mmochi AJ (2012) Isotopic and microbial indicators of sewage pollution from Stone Town, Zanzibar. Tanzania. Mar Pollut Bull 64(7):1348-1355

Nassar MZ, Mohamed HR, Khiray HM, Rashedy SH (2014) Seasonal fluctuations of phytoplankton community and physico-chemical parameters of the north western part of the Red Sea, Egypt. Egypt J Aquat Res 40(4):395-403

Nzali LM, Johnstone RW, Mgaya Y (1998) Factors affecting scleractinian coral recruitment on a nearshore reef in Tanzania. Ambio 27(8):717-722

Panda SS, Dhal N, Panda C (2012) Phytoplankton diversity in response to abiotic factors along Orissa coast, Bay of Bengal. Int J Environ Sci 2:3-8

Parsons TR, Maita Y, Lalli M (1984) A manual of chemical and biological methods for seawater analysis. Pergamon Press, Oxford, p 173

Peter N (2013) Phytoplankton distribution and abundance along Zanzibar and Pemba Channels. M.Sc. Thesis, University of Dar es Salaam, Dar es Salaam, Tanzania, pp 105

Rahaman S, Golder J, Rahaman M, Hasanuzzaman A, Huq K, Begum S, Islam S, Bir J (2013) Spatial and temporal variations in phytoplankton abundance and species diversity in the Sundarbans mangrove forest of Bangladesh. J Mar Sci Res Dev 3(2): $1-9$

Richard WJ, Stickley CE (2010) Diatoms as biondicators of paleoceanographic events. In: Smol JP, Stoermer EF (eds) The diatoms: applications for the environmental and earth sciences. Cambridge University Press, Shaftesbury Road, Cambridge, pp 424-452

Richmond MD (ed) (2011) A field guide to the seashores of Eastern Africa and Western Indian Ocean Islands, Sida/ WIOMSA-UDSM. Eurolitho, Milano, p 464

Rosenwasser S, Graff van Creveld S, Schatz D, Malitsky S, Tzfadia O, Aharoni A, Levin Y, Gabashvili A, Feldmesser E, Vardi A (2014) Mapping the diatom redox-sensitive proteome provides insight into response to nitrogen stress in the marine environment. Proc Natl Acad Sci 111(7):2740-2745

Round FE, Crawford RM, Mann DG (1990) The diatoms: biology and morphology of the genera. Cambridge University Press, Cambridge, p 747

Sachithanandam V, Mohan P, Karthik K, Elangovan SS, Padmavathi G (2013) Climate change influence the phytoplankton bloom (Prymnesiophyceae: Phaeocystis spp.) in North Andaman coastal region. Indian J Geo Mar Sci 42:58-66

Saifullah ASM, Abu Hena MK, Idris MH, Halimah AR, Johan I (2014) Composition and diversity of phytoplankton from mangrove estuaries in Sarawak, Malaysia. J Biol Sci 14(5):361-369

Santos S, Shearer T, Hannes A, Coffroth M (2004) Fine-scale diversity and specificity in the most prevalent lineage of symbiotic dinoflagellates (Symbiodinium, Dinophyceae) of the Caribbean. Mol Ecol 13(2):459-469

Saravanakumar A, Rajkumar M, Thivakaran G, Serebiah JS (2008) Abundance and seasonal variations of phytoplankton in the creek waters of western mangrove of Kachchh-Gujarat. J Environ Biol 29(2):271

Shannon CE, Weaver W (1949) The mathematical theory of communication. Urbana University Illinois Press, Illinois, p 117

Siyambalapitiya S, Ranatunga R, Gunasekara A (2012) Plankton composition and potential of contaminating alien species via ballast water discharged in Colombo harbor. In: Proceedings of 15th International Forestry and Environment Symposium 26-27 November 2010. Published by Department of Forestry and Environmental Science, University of Sri Jayewardenepura, Sri Lanka, pp 40-46

Stanca E, Roselli L, Durante G, Seveso D, Galli P, Basset A (2013) A checklist of phytoplankton species in the Faafu atoll (Republic of Maldives). Transit Water Bull 7(2):133-144

Strutton PG, Coles VJ, Hood RR, Matear RJ, McPhaden MJ, Phillips HE (2015) Biogeochemical variability in the central equatorial Indian Ocean during the monsoon transition. Biogeosciences 12(8):2367-2382

Suckall N, Tompkins E, Stringer L (2014) Identifying trade-offs between adaptation, mitigation and development in community responses to climate and socio-economic stresses: evidence from Zanzibar, Tanzania. Appl Geogr 46:111-121

Szmant A (2002) Nutrient enrichment on coral reefs: Is it a major cause of coral reef decline? Estuaries 25(4):743-766

Tantanasarit C, Englande AJ, Babel S (2013) Nitrogen, phosphorus and silicon uptake kinetics by marine diatom Chaetoceros calcitrans under high nutrient concentrations. J Exp Mar Biol Ecol 446:67-75

Tchernov D, Gorbunov MY, de Vargas C, Yadav SN, Milligan AJ, Häggblom M, Falkowski PG (2004) Membrane lipids of symbiotic algae are diagnostic of sensitivity to thermal bleaching in corals. Proc Natl Acad Sci USA 101(37):13531-13535

Tomas CR (1997) Identifying marine phytoplankton. Academic Press, California, p 858

Turner RE, Rabalais NN (2013) Nitrogen and phosphorus phytoplankton growth limitation in the northern Gulf of Mexico. Aquat Microb Ecol 68(2):159-169

Yin K (2002) Monsoonal influence on seasonal variations in nutrients and phytoplankton biomass in coastal waters of Hong Kong in the vicinity of the Pearl River estuary. Mar Ecol Prog Ser 245:111-122 